\title{
Utilization of Coffee Silverskin as Natural Antimicrobial in Staphylococcus aureus Bacteria
}

\author{
Devy Cendekia ${ }^{1}$, Analianasari Analianasari ${ }^{2}$, Widia Hartini ${ }^{4}$ \\ ${ }^{1}$ Industrial Chemical Engineering Departement, Politeknik Negeri Lampung, Bandar \\ Lampung, Indonesia \\ ${ }^{2 *}$ Agroindustry Product Development Departement, Politeknik Negeri Lampung, \\ Bandar Lampung, Indonesia \\ ${ }^{3}$ Estate Crops Department, Politeknik Negeri Lampung, Bandar Lampung, Indonesia \\ "Corresponding author: analianasari@polinela.ac.id
}

\begin{abstract}
The research aims (1) to analyze the antimicrobial inhibition of waste of coffee beans (coffee silverskin) from Staphylococcus aureus; (2) Studying the characteristics of antimicrobial activity of coffee bean epidermis in Staphylococcus aureus bacteria and (3) Determining the exact concentration of antimicrobial waste of coffee beans from coffee beans (coffee silverskin ) on Staphylococcus aureus bacteria. The research method used was an experimental method, which is to conduct antimicrobial experiments on coffee silverskin. The design used is Completely Randomized Design (CRD) 1 factor, which as a treatment is silverskin coffee extract consisting of 4 levels of treatment namely $25 \%, 50 \%, 75 \%$, and $100 \%$. The parameters observed in this study were antimicrobial inhibition, antimicrobial characteristics of coffee silverskin, and the best antimicrobial concentration of coffee silverskin. Based on research results that Robusta coffee bean extract can inhibit Staphylococcus aureus bacteria. The antibacterial activity of Robusta coffee bean extract with a concentration of $75 \%$ resulted in an inhibition zone diameter greater than other concentrations of $1.22 \mathrm{~mm}$.
\end{abstract}

\section{Introduction}

Coffee is the most popular drink in the world because its consumption demand is always increasing [1]. Based on the Center for Agricultural Data and Information System of the Ministry of Agriculture, the national coffee consumption in 2016 reached around 250 thousand tons and grew $10.54 \%$ to 276 thousand tons. Indonesian coffee consumption throughout the 2016-2021 period is predicted to grow an average of $8.22 \%$ / year. In 2021, coffee supply is predicted to reach 795 thousand tons with a consumption of 370 thousand tons, resulting in a surplus of 425 thousand tons [2].

When is the consumption of coffee is not just a sleep-busting drink, but it has become a lifestyle. It is seen increasingly coffee shop drinks from brew coffee in Indonesia, especially in Bandar Lampung. The production of ground coffee in the processing, of course, produces coffee husk waste as much as $40-45 \%$. Coffee husk waste consists of pulp (mesocarp part), peel (exocarp part), mucilage, and parchment (endocarp part) [3].

Waste leather coffee especially peels epidermis is only used for the intake of feed animals and as organic fertilizer. The lack of concern for the community and the lack of information on the benefits of coffee bean epidermis is the cause of the inadequate utilization and processing of waste of peel epidermis bean coffee [4]. [1] reported that the epidermis is a thin legume that directly covers the 
coffee beans. During the process of roasting (baking), bean coffee expands and layers of thin it part, into the product side of the primary of the process of roasting.

[1] in his review stating that the peel epidermis bean coffee has a bioactive that potential as (1) anti-aging because it has antioxidants that high (compound phenolic, melanoidin, and the content of caffeine ); (2) Anti-inflammatory because the epidermis of coffee beans contains melanoidin; (3) antimicrobial because the peel of the coffee beans contains chlorogenic acid and caffeine [5].

[6] This shows that the activity of the antimicrobial extract of the peel epidermis bean coffee is very good against the pathogen Staphylococcus aureus (ATCC 6538 and MRSA), Staphylococcus epidermis, Escherichia coli (ATCC 1576 and MRSA), and Klebsiella pneumonia (ATCC4352).

Staphylococcus aureus is a bacterial pathogen that causes disease infection Staphylococcus aureus coined the characteristics as follows : (1) the form of spherical with a diameter of 0.7 to 1.2 $\mu \mathrm{m}$, (2) the composition of the group who do not regularly as fruit wines, (3) anaerobic facultative, (4) does not have a spore and moves, and (5) types of gram-positive bacteria. Bacteria Staphylococcus aureus can be found on the surface of the peel as normal flora, especially around the nose, mouth, tools genitals, and around the anus. Many diseases dangerous can be caused by bacteria, such as meningitis, endocarditis, and infection of the lungs. The bacteria are also often lead poisoning due to contaminated food.

Bacteria that cause several diseases in humans cause humans to handle them in addition to using drugs as well as using antibiotics. People in using antibiotics tend to be excessive so that in just 4 years there will be problems with antibiotic resistance with all the very detrimental consequences [7]. [8] said that resistance accurate rate Staphylococcus aureus against antibiotics in Asia is already quite high, such as in Taiwan $60 \%$, China $20 \%$, Philippines $5 \%$, and Singapore $60 \%$. To cope with the increase in resistance to microbial pathogens, then the necessary research on materials that are sourced from nature who coined the potential antimicrobial is high. Usage of phytochemicals as agents antimicrobial naturally, the usual so-called "biocides", increasingly popular. Invitro antibacterial activity of coffee beans against Gram-positive and Gram-negative bacteria has also been carried out. Besides that, various materials chemically active naturally in coffee with heavy molecular low as trigonelline, caffeic acid, and acid 5-caffeoylquinic has demonstrated activity that is good against the growth of Legionella pneumophila, Enterobacteria, and S. mutants [9]. Because it is important to do the potential waste of peel epidermis bean coffee (silver peel coffee) as antimicrobial natural to increase the value-added waste coffee.

The research aims to (1) analyze power resistor antimicrobial waste silver peel coffee bean in bacteria Staphylococcus aureus ; (2) Learn the characteristics of the activity of the antimicrobial waste silver peel coffee bean in bacteria Staphylococcus aureus and (3) Determining the concentration of the appropriate antimicrobial waste silver peel coffee bean in bacteria Staphylococcus aureus.

\section{Methods}

Materials were used in the study is that Limbak Leather Ari bean coffee that comes from cooperative Fiesta Coffe Lampung, ethanol 70\%, Buffered Peptone Water (BPW), media Mac Conkey Agar (MCA), the media selectively Staphylococcus, distilled water, alcohol 70\%, aluminum foil, cotton, and paper discs.

The tools used in this research are knife, basin, blender, filter paper, macerator, beaker glass, Erlenmeyer, Petry dish, water bath shaker, vacuum rotary evaporator, measuring cup, stirrer, incubator, dropper, colony counter, autoclave, and other tools. other laboratories.

The samples were used in the study are that peel epidermis bean coffee (bark silver) and then dried. Once that is done sorting dried and smoothed by way of blended then sieved with a sieve no. 40 until a homogeneous fine powder is obtained.

Extraction $100 \mathrm{~g}$ peel epidermis bean coffee by way of maceration using solvent alcohol $70 \%$ obtained extract thick. Evaluation of the activity of the antimicrobial Bacteria are used in research this is Staphylococcus aureus. The medium used is Nutrient Agar (NA). The testing technique was 
developed from the Kirby-Bauer method. The method that is used in the testing of the activity is the method of diffusion in order by way of a diffusion plate. Procedure Testing antibacterial did by testing out as much as $50 \mathrm{~mL}$ extract of the peel epidermis bean coffee in paper disc placed on each well which has been made in the media Nutrient Agar (NA). The concentration of the extract was tested are $250 \mathrm{ppm}, 500 \mathrm{ppm}, 750 \mathrm{ppm}$, and $1000 \mathrm{ppm}$ [10]. The control positive that is used is Tetracycline to a concentration of $0.1 \%$. Determination of the response power resistor using the method of Davis Stout's (Table 1). The antibacterial effectiveness of the test extract was calculated using the formula :

$\mathrm{E}=\mathrm{Dz} / \mathrm{Da} \times 100 \%$

Where :

$\mathrm{E}=$ Antibacterial effectiveness (\%)

$\mathrm{Dz}=$ Diameter of antibiotic inhibition zone $(\mathrm{mm})$

$\mathrm{Da}=$ Diameter of the test extract inhibition zone $(\mathrm{mm})$

\section{Results and Discussion}

3.1 Silverskin Coffee Bean Extract

Extraction Powder peel epidermis bean coffee put into the flask, then soaked in a solution of ethanol $96 \%$ as much as $225 \mathrm{~mL}$, covered with aluminum foil, and left for 5 days while occasionally stirring. After 5 days, the samples were soaked it was filtered using a paper filter produces filtrate 1 and dregs 1. dregs that there are then extracted. The extraction process in this study uses the maceration method. Methods maceration is very beneficial in the insulating compound material nature or substance sea because by soaking the sample will occur breakdown the walls of cells and membranes of cells due to differences in pressure between at the inside and outside of the cell, so that the metabolite of the secondary will be dissolved in solvents organic and extraction of the compound will be perfect because it can the set of immersion are performed. The advantage of the method is, that is to avoid damage to the substance acts as a result of heating the excess.

The selection of the solvent, in general, is influenced by several factors among others, selectivity, solubility, and the point of boiling. For the extraction solvent itself, ethanol is used. Solvent ethanol is a solvent that is not toxic and is universally suitable to extract all the class of compounds metabolites secondary. In addition to the solvent ethanol has the properties of a selective, can be mixed with water at any ratio, economical, able to extract the largest compound chemical that is contained in the crude drugs such as alkaloids, oils essential, glycosides, curcumin, chlorophyll, steroids, and flavonoids. Results maceration of the peel epidermis coffee robusta form of the filtrate is colored brown-black as much as $10 \mathrm{ml}$. Furthermore, the filtrate is evaporated using a rotary evaporator to obtain the extract condensed as much as $5 \mathrm{ml}$ brown-black extract.

\subsection{Antibacterial Activity Test}

In the test, the activity of antibacterial extract of the peel epidermis bean coffee robusta is using methods diffusion agar (diffusion Kirby-Bauer that has been modified) by the method of discs into a choice in achieving the purpose of the clinical are often used to test the sensitivity of antibiotics. The result of the activity of antibacterial obtained through observations was carried out during $1 \times 24$ hours of incubation with 3 times repetitions for each bacterium. After a period of incubation to form regional nodes in the surrounding discs form a circle. Regional lymph is a manual sensitivity of bacteria to antibiotics which are used as control positive or materials antibacterial others are used as material tests expressed by the width of the diameter of the zone inhibition.

Dick positive was used in the study is that tetracycline. The function of the tetracycline is like the control of substances test by comparing the diameter of the area resistor are formed, while the control negative which is used is water. The function of the negative control is to determine whether there is a solvent influence on the growth of the Streptococcus aureus bacteria so that it can be seen that the one that has antibacterial activity is the non-solvent test substance. The result of the activity of antibacterial and results from measurement zone diameter of inhibition extract peel epidermis bean coffee robusta against bacteria Streptococcus aureus can be seen in Table 1. 
Table 1. The average diameter of the power resistor on the bacteria Staphylococcus aureus

\begin{tabular}{clllc}
\hline Concentration(\%) & Repetition1 & Repetition 2 & Repetition 3 & Average \\
100 & 1,1 & 0,8 & 0,85 & 0.92 \\
75 & 1,15 & 1,2 & 1,3 & 1.22 \\
50 & 1 & 0,70 & 0,95 & 0.88 \\
25 & 0,80 & 0,55 & 0,6 & 0.65 \\
\hline
\end{tabular}

The results of the measurement of the diameter of zone of inhibition through measurement with a ruler scale can be known that the extract of the peel epidermis bean coffee robusta has a diameter equal to tetracycline in inhibiting bacteria Streptococcus aureus. Results of inhibition can be seen in Figure 1.

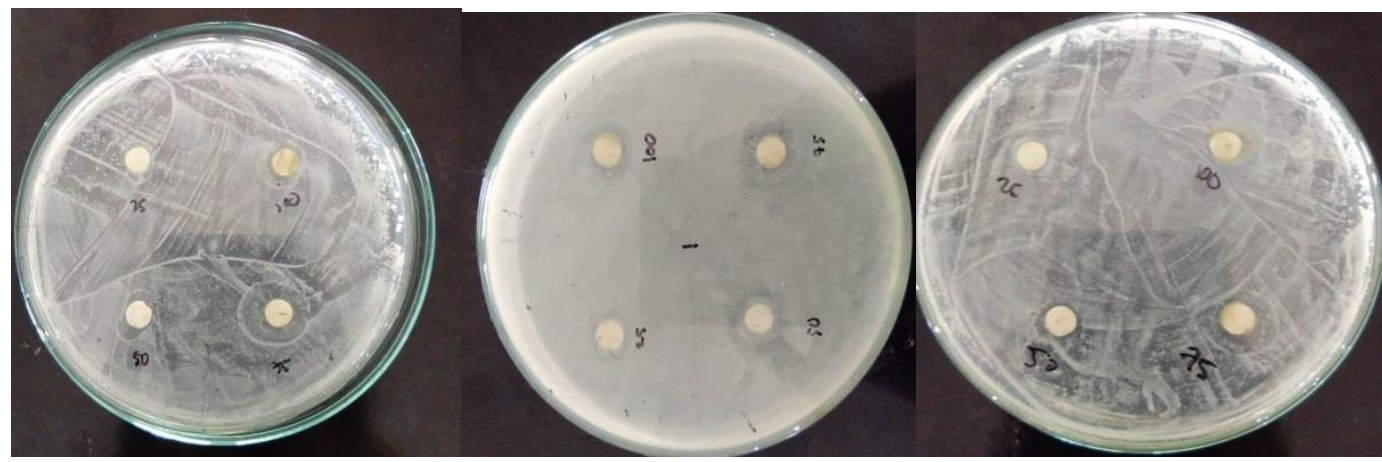

Figure 1. Inhibition of silver peel coffee bean extract

\section{Conclusions}

Based on the results of the research can be concluded that the extract of the peel epidermis bean coffee robusta can inhibit the bacteria Staphylococcus aureus. Activities antibacterial extract of the peel epidermis bean coffee robusta with a concentration of $75 \%$ resulted in diameter zone of inhibition is more substantial than the concentration of other, namely by $1.22 \mathrm{~mm}$.

\section{Acknowledgments}

This pepper has emerged from the research conducted as part of the project funded by DIPA Politeknik Negeri Lampung with grant number: 066.78/PL15.8/PM/2019

\section{REFERENCES}

[1] Bessada, S.M.F., Alves, R.C. \& Oliveira, M.B.P.P. 2018. Coffee Silverskin: A Review on Potential Cosmetic Applications. Cosmetics, 5(5): 1-11. Tersedia di \%0Awww.mdpi.com /journal/cosmetics.

[2] Triyanti, D.R. 2016. Oulook Kopi Komoditas Pertanian Subsektor Pekebunan. Jakarta: Pusat Data dan Sistem Informasi Pertanian Sekretariat Jenderal - Kementerian Pertanian.

[3] Esquivel, P. \& Jiménez, V.M. 2012. Functional properties of coffee and coffee by-products 放. Food Research International, 46(2): 488-495. Tersedia di http://dx.doi.org/10.1016/j. foodres.2011.05.028.

[4] Marcelinda, A., Ridhay, A. \& Prismawiryanti, P. 2016. Aktivitas Antioksidan Ekstrak Limbah Kulit Ari Biji Kopi ( Coffea sp ) Berdasarkan Tingkat Kepolaran Pelarut. Jurnal of Natural 
Science, 5(1): 21-30.

[5] Costa, A.S.G., Alves, R.C., Vinha, A.F., Barreira, S.V.P., Nunes, M.A., Cunha, L.M. \& Oliveira, M.B.P.P. 2014. Optimization of antioxidants extraction from coffee silverskin, a roasting byproduct, having in view a sustainable process. Industrial Crops \& Products, 53: 350-357. Tersedia di http://dx.doi.org/10.1016/j.indcrop.2014.01.006.

[6] Rodrigues, F., Palmeira-de-oliveira, A., Neves, J. das, Amaral, M.H., Oliveira, M.B.P.P., Rodrigues, F. \& Sarmento, B. 2015. Coffee silverskin : A possible valuable cosmetic ingredient. Pharmaceutical Biology ISSN:, 209: 386-394.

[7] Farida, H., Notoatmodjo, H., Herawati, H., Hapsari, M. \& Hardian, H. 2008. Penggunaan Antibiotik Secara Bijak Untuk Mengurangi Resistensi Antibiotik, Studi Intervensi di Bagian Kesehatan Anak RS Dr. Kariadi. Sari Pediatri, 10(1): 34-4

[8] Zukhri, S. \& Hidayati, N. 2017. AKTIVITAS ANTIMIKROBA EKSTRAK ETANOL PELEPAH PISANG RAJA ( Musa x paradisiaca L .) PADA BAKTERI Staphylococcus Auresus. GASTER, XV(2): 216-231.

[9] Sousa, C., Pessoa, U.F. \& Pessoa, U.F. 2015. Coffee industrial waste as a natural source of bioactive compounds with antibacterial and antifungal activities Coffee industrial waste as a natural source of bioactive compounds with antibacterial and antifungal activities. Science, Technological Advances and Educational Programs (A. Méndez-Vilas, Ed.), (May 2016): 130 136.

[10] Muslim, Z. \& Dephinto, Y. 2017. Perbandingan Efektivitas Antimikroba Ekstrak Daun Kopi Robusta ( Coffea Canephora) Dengan Variasi Pengeringan Terhadap Escherichia coli. Jurnal Sains dan Teknologi Farmasi, 19(Desember): 86-88. 